\title{
Princípio de razão e o "conhecimento das causas": considerações sobre o valor fundamental da verdade e o seu sentido
}

Principle of Reason and "Knowledge of Causes": Considerations on the Inner Value of Truth and its Meaning

* Dax Moraes

Resumo: As críticas nietzscheanas dos valores e da verdade dirigem-se a um tipo da vontade que exige do mundo uma causa universal que lhe sirva como explicação. O presente ensaio concentra-se no significado fundamental desse sentimento comum à ciência e à religião enquanto resposta à total ausência de sentido, uma vez que o sentido de cada coisa, na existência, não se deve a nada mais senão à nossa própria criação.

Palavras-chave: Causalidade. Vontade. Verdade. Ciência. Realidade.

Abstract: Nietzsche's criticisms of values and truth are directed to a kind of will which requires an universal cause for the world as a mean to its explanation. This essay focuses on the inner meaning of that common felling in science or religion as a response to our intrinsic complete lack of meaning, since the meaning of everything in life is not due to anything else but to our own creation.

Keywords: Causality. Will. Truth. Science. Reality.

Nietzsche, seguindo a temerária trilha aberta por pensadores tão diferentes como Hume, Kant e Schopenhauer no que se refere à crítica da perspectiva realista acerca da causalidade, diagnostica a fé científica em uma ordem causal e em uma finalidade intrínsecas à natureza como índices de uma vontade de verdade comum ao espírito metafísicoreligioso. Não será por uma causa cética ou ateísta que a sua obra

* Doutor em Filosofia pela Universidade Federal do Rio Grande do Norte (UFRN). Professor Adjunto III na Universidade do Estado do Rio Grande do Norte, Curso de Filosofia (CaC/UERN).

\begin{tabular}{|l|l|l|l|l|l|}
\hline Veritas & Porto Alegre & v. 58 & n. 3 & set./dez. 2013 & p. 610-626 \\
\hline
\end{tabular}


se moverá, mas sim o contrário: a sua obra, em suas mais polêmicas asserções, antes desemboca na crítica da ciência e da religião como modos de pensar próprios ao crente. Quem é esse crente? Aquele que, por uma carência de sentido próprio, por uma necessidade de explicações, por uma fuga em face do nada, da ausência de fundamento, toma o efeito pela causa, ou seja, o fato de já sempre imprimirmos no mundo uma ordem nos parecer como a apreensão de uma verdade que nos é extrínseca. Por essa crença, a causalidade é estimada como uma realidade em si e, por conseguinte, e apenas segundo esse pressuposto, um primeiro princípio parece exigido. Sobre esse pilar do saber universal construímos castelos suntuosos, esquecidos da verdade mais profunda de que, sob nossa glorificada civilização, há tão-somente um abismo. Ao invés de, no entanto, advogar a causa de vivermos na irrazão, Nietzsche aponta para um horizonte de liberdade, perspectiva segundo a qual somos antes a liberdade de nossa própria criatividade, somos a nossa própria fatalidade, não meros produtos de uma inteligência oculta e insondável. O mundo se desvela como nosso próprio produto ao invés de ter a sua essência definitivamente fechada como que por um ceticismo radical e intransigente. Antes de negar a existência de Deus ou verdades absolutas, Nietzsche constata o vazio daquilo de que são expressão: a causa última do que conhecemos e vivemos:

Não se deve coisificar erroneamente 'causa' e 'efeito', como fazem os pesquisadores da natureza (e quem, assim como eles, atualmente 'naturaliza' no pensar), conforme a tacanhez mecanicista dominante, que faz espremer e sacudir a causa, até que 'produza efeito'; deve-se utilizar a 'causa', o 'efeito', somente como puros conceitos, isto é, como ficções convencionais para fins de designação, de entendimento, não de explicação. No 'em si' não existem 'laços causais', 'necessidade', 'não-liberdade psicológica', ali não segue 'o efeito à causa', não rege nenhuma 'lei'. Somos nós apenas que criamos as causas, a sucessão, a reciprocidade, a relatividade, a coação, o número, a lei, a liberdade, o motivo, a finalidade; e ao introduzir e entremesclar nas coisas esse mundo de signos, como algo 'em si', agimos como sempre fizemos, ou seja, mitologicamente ${ }^{1}$.

Como é possível, depois disso, conceber-se um Deus-Criador? Apesar do caráter estranhamente categórico da afirmação de Nietzsche acerca da inexistência de laços causais, cuja justificativa é estritamente schopenhaueriana em última análise, a sua tese remonta a Hume, de

Cf. NIETZSCHE, F. W. Além do bem e do mal: prelúdio a uma filosofia do futuro. Trad. Paulo César de Souza. São Paulo: Companhia das Letras, 1996, § 21. A partir daqui, ABM... 
quem também Kant tomara impulso para preencher a problemática lacuna deixada pela obra do cético escocês. Apenas por sua própria atividade o homem pode crer em causas eficientes, de maneira que a ação humana se converte em tudo que há de real. A postulação de uma causa-primeira, seja de que espécie for, mesmo que admitida apenas pragmaticamente, é componente fundamental do que Nietzsche denominará "vontade de verdade", isto é, o impulso da razão em sacrificar tudo e todos no interesse do saber seguro segundo o velho pressuposto de que para tudo há uma razão suficiente. A vontade de verdade constitui, para ele, a crença inaugural de toda forma de niilismo, a certeza calcada no mito. "Essa crença, que está na base da religião, da filosofia, de que nada é mais necessário do que o verdadeiro, crença no caráter absoluto, inestimável, incriticável da verdade, no valor em si da verdade é o que Nietzsche chama de "vontade de verdade'" 2 . Pode-se, contudo, problematizar o que é dito em seguida por Machado": "A vontade de verdade, que se encontra na base tanto da metafísica quanto da religião, esclarecendo inclusive a homogeneidade que existe entre elas, é uma vontade moral". A vontade moral não pode ser anterior à vontade de verdade em sentido lato, justamente porque toda vontade moral se justifica no pré-conceito ou na exigência da verdade moral a ser buscada quando a própria moral se torna uma exigência da vontade em geral. Muito embora as palavras de Machado estejam de acordo com o que diz Nietzsche, flagramos aí uma limitação de sua genealogia, que, como tal, toma o mundo da vida e dos negócios cotidianos como o seu ponto de partida. De todo modo, o sentido utilitário do ser-verdadeiro deve preceder, mesmo genealogicamente, o sentido moral, não se podendo dizer que apenas esse último provenha de uma vontade (de poder) dirigida à conformação dos entes. Segundo o próprio Nietzsche, a verdade se torna instrumento anterior e independentemente da moralização. É necessário que a verdade seja reconhecida como útil para que qualquer coisa "verdadeira" receba atenção, pois a mera precisão de uma moral não exige dela veracidade, bastando que se tenha fé que se trata do melhor - com efeito, um conceito dos mais vagos e obscuros. Apenas quando a verdade é identificada ao bem (que se quer) e contraposta à aparência pode ela ser elevada a valor de todos os valores, bem dos bens, e então adquirir valor moral - não seria esse o tema da "Primeira dissertação" da Genealogia

2 Cf. MACHADO, R. Zaratustra: tragédia nietzschiana. Rio de Janeiro: J. Zahar, 1997, p. 66; cf. ABM, § 34; NIETZSCHE, F. W. A gaia ciência. Trad. Paulo César de Souza. São Paulo: Companhia das Letras, 2004, § 344 (a partir daqui, GC...); NIETZSCHE, F. W. Genealogia da moral: uma polêmica. Trad. Paulo César de Souza. São Paulo: Companhia das Letras, 1999, § 24 (a partir daqui, GM...).

3 Cf. MACHADO, R. Zaratustra: tragédia nietzschiana, p. 66-67. 
da moral? Nessa elevação - de espécie a gênero supremo -, a verdade como um todo decai, como o homem quando colocado no topo do reino animal. (Trata-se também de um problema lógico-gramatical, pois a singularização do ente se dá aí por predicação, ou seja, pela remissão a um gênero, a um conceito. Enquanto ente formado linguisticamente, o homem faz da linguagem o fundamento de uma ontologia da decadência).

Nesse caso, deve-se compreender que vontade é essa e qual o papel da moral na afirmação do poder - para Nietzsche, a vontade de poder dos fracos, os quais não dominariam senão pelo ideal ascético. Apenas, portanto, quando verdade e mentira se contrapõem no discurso e o mundo é partido em seus respectivos "domínios", e aquilo que se atribui ao reino da verdade passa a ser definido como Bem, ocorrendo uma inversão, operada por Platão, se reconhece a verdade onde se encontra o bem - aí então temos um "preconceito moral". Desse modo, o que é dito no $\S 34$ de Além do bem e do mal, no § 344 de A gaia ciência ou no § 24 da "Terceira dissertação" da Genealogia da moral se refere a um mundo já cindido entre real e aparente por representações metafísicas, somente após o que o verdadeiro é exaltado como valor de todos os valores, dando início à história do niilismo. A "genealogia da verdade", a nosso ver, se encontra, do ponto de vista do conhecimento e da linguagem, no fragmento "Sobre verdade e mentira" - onde se deve grifar "no sentido extramoral" -, indicando, à luz da obra posterior de Nietzsche, que, enquanto criações humanas, pela transvaloração, são possíveis e vantajosas verdades e mentiras no sentido extramoral, desde que se supere a sua moralização. Assim, reconhecida a correção das palavras de Machado, devemos, contudo, relativizar a redução, sem mais, da vontade de verdade à vontade moral, pois se trata aí de uma determinada interpretação, já decaída, da "verdade".

No que concerne à crítica nietzscheana dos valores, que se dirige à questão do niilismo, é de grande relevância o caráter fundamentalmente ambíguo do niilismo. O seu ponto de inflexão se dá na modernidade, quando a vontade de verdade se mostra como vontade de dúvida. Esta última é o próprio motor de uma racionalidade que se limitou a si mesma, ou seja, uma vez que se estabelecem os limites da razão, os mesmos são artificialmente estendidos ao infinito, na medida em que sempre se pode duvidar do conhecido. Tal empenho não apenas acirra o interesse exploratório em busca de erros como torna o pensamento mais e mais abstrato. O momento crucial é aquele em que têm início o que Schopenhauer ${ }^{4}$

4 Cf. SCHOPENHAUER, A. Le monde comme volonté e comme représentation. Trad. A. Burdeau. 2. ed. rev. e corr. por Richard Ross. Pref. Clément Rosset. Paris: Presses Universitaires de France, 2004, § 5, p. 38. 
qualifica como "discussões absurdas sobre a realidade do mundo exterior"

Todo o mundo objetivo é e permanece representação, e, por esta razão, é absoluta e eternamente condicionado pelo sujeito; em outros termos, o universo tem uma idealidade transcendental. Não resulta disto que ele seja ilusão ou mentira; ele se dá por aquilo que é, por uma representação, ou antes uma sequência de representações cujo elo comum é o princípio de causalidade. Assim considerado, o mundo é inteligível para um entendimento sadio, e isso em seu sentido mais profundo; ele lhe fala em uma língua que se deixa compreender inteiramente. Somente uma inteligência falseada pelo hábito das sutilezas pode precaver-se contestando-lhe a realidade ${ }^{5}$.

Depreende-se dessas palavras que a dúvida acerca da realidade do mundo exterior deve ser compreendida como uma espécie de perversão do pensamento. É claro que, por um lado, parece filosoficamente legítimo espantar-se diante do fato de que provas e soluções para esse "problema" são impossíveis. Por outro lado, como propriamente faz a metafísica que se quer ciência, tal espanto termina por ser danoso ao pensamento. A evidência de que há mundo, impropriamente concluída do fato de que ele nos afeta, em primeiro lugar torna o seu questionamento absurdo e indigno. Partindo dessa evidência mal compreendida, a ciência se obriga a se ater ao dado. Essa atitude supõe o mesmo preconceito do senso comum: o de que há um eu e um não-eu, entre os quais a inteligência é capaz de estabelecer uma ponte. O empenho na construção dessa ponte insiste e consolida a separação mal compreendida entre sujeito e objeto. Uma vez que se pressupõe entre um e outro uma causalidade e se afirma que a causalidade é mera representação, torna-se possível concluir, com Hume, que a causalidade é tirada da experiência, quando, em verdade, esta a supõe, conforme critica Schopenhauer no mesmo lugar. De todo modo, há nessa controvérsia uma confusão entre causalidade como condição de toda experiência e juízo causal. Hume, diferente de Kant e Schopenhauer e neste caso mais próximo de Nietzsche, não tratava senão do juízo causal, do ponto de vista do conhecimento, não de seu fundamento. Essa distinção é fundamental para que se reconheça o mérito de Hume, ao confessar que a ideia de causalidade vem apenas preencher a posteriori uma lacuna da experiência já adquirida, na medida em que, sendo esta adquirida mediante impressões habituais de conjunções entre fatos, hábito aprendido mediante a semelhança entre conjunções ocorridas no presente (presentes na sensação) e no passado (presentes

5 Ibid., § 5, p. 39-40. 
na memória), sentimos internamente tais conjunções como expressões de uma conexão intrínseca entre os fatos. A lacuna pode ser explicitada apontando-se aí uma petição de princípio: a explicação para que certos fatos costumeiramente ocorram em uma dada sequência pressupõe já alguma coisa, a saber, a exigência de um porquê para a semelhança como tal, e não apenas para a sua representação. Não se trata somente de explicar por que um fato sucede outro, mesmo porque uma sequência original não o permite, mas porque a sequência se dá regularmente. Dito de outro modo, não se trata apenas de atribuir à relação entre um fato $A$ e um fato $B$ uma relação causal, mas de explicar por que a sucessão entre $A$ e $B$ é semelhante à sucessão entre $C$ e $D$ - a resposta é: considerandose a semelhança entre $A$ e $C$ e entre $B$ e $D$, o que causa $B$, i.e. $A$, deve ser semelhante ao que causa $D$, i.e. $C$, concluindo-se que $A$ está para $C$ assim como $B$ está para $D$. Trata-se de um raciocínio analógico em que as semelhanças entre os antecedentes e os seus respectivos sucessores são já pressupostas para se concluir por sua identificação, atribuindo-se a ambas as sequências o mesmo mecanismo. Com a aparente repetição das conjunções, conclui-se pela causalidade como causa das repetições elas mesmas. Seguindo rigorosamente os seus princípios, na ausência de uma experiência exterior da causalidade como tal, Hume a remete à experiência interior que denomina sentimento. O que Kant fará será explicar esse "sentimento" como forma da experiência possível. Hume, portanto, diz apenas como aprendemos a causalidade, não por que ou como podemos aprendê-la, exceto pela conjetura de que tal sentimento provenha de algum instinto próprio à natureza humana dada a sua utilidade - ao contrário, confessa uma deficiência da razão mantendo impensada a noção de "causa" para além dos limites da experiência imediata, tendo, contudo, o mérito de chamar a atenção para o problema:

A frequência com que se usam termos como 'força', 'poder', 'energia', etc., em todos os momentos da vida diária e em filosofia, não é uma prova [de] que conhecemos em quaisquer dos casos o princípio de conexão entre a causa e o efeito ou que podemos dar uma explicação conclusiva da produção de uma coisa pela outra. Estes termos - tais como são geralmente empregados - têm sentido muito vago e as suas ideias são bastante incertas e confusas ${ }^{6}$.

Enfim, a mal compreendida certeza de si mesmo conduz a todo tipo de teoria acerca da natureza da ligação entre eu e mundo, seja mediante uma cartesiana prova da existência de Deus, seja mediante a doutrina

6 Cf. HUME, D. Investigação acerca do entendimento humano. Trad. Anoar Félix. São Paulo: Nova Cultural, 1996, Seção VII, Parte 2, p. 87, n. 2. 
psicológica de Hume. Um e outro pretendiam explicar, em última análise, como afinal se dá a ação do mundo sobre mim e minha ação sobre o mundo sem jamais colocar em questão o afetar. Cada qual a seu modo, resguardadas as suas imensas diferenças de orientação - e isso é notável! -, questionava-se em que medida o que sinto em mim pode ser atribuído a algo real fora de mim, e em que medida. É por isso que dizer "O mundo é em mim" ou "Sou no mundo" mantém sempre eu e mundo como entidades dadas separadamente. A conpertinência fundamental expressa na palavra "ser-no-mundo" é encoberta na justaposição representada pelo intelecto. O que a impossibilidade da prova nos mostra é que, mais justamente, devemos nos surpreender diante da inseparabilidade de dentro e fora, alma e corpo, dimensões postas segundo interpretações de "ser-no-mundo". A fuga da impossibilidade da prova exige a referida ponte, a qual, porém, jamais sustentará por muito tempo o nosso próprio peso. O outro lado do problema consiste em que, sendo impossível a prova mesmo para aquilo que há de mais evidente - sermos no mundo -, nos vemos desconfiados de todo o resto, alimentando assim a nossa ânsia por explicações. As evidências são postas de lado, pois, afinal, são dados dos quais só se pode deduzir, jamais ir mais acima. Trata-se de uma atitude não-filosófica em sentido próprio, na medida em que só resta lugar para espanto em face do extraordinário. Quando, então, dizemos que há algo de legitimamente filosófico no questionamento acerca da realidade, referimo-nos ao que isso significa existencialmente, ou seja, o que diz acerca de nós mesmos - por isso mesmo, a questão não deve ser ignorada, mas, em vez de buscar-lhe uma solução, deve-se encontrar-lhe o sentido.

As palavras de Schopenhauer dizem muito a este respeito. Pela expressão "idealidade transcendental", Schopenhauer afirma que já sempre somos no mundo e que toda relação fenomenal é mera representação. Portanto, embora muitas vezes Schopenhauer afirme que o mundo como representação é ilusório, fictício, etc., está se referindo não ao mundo como tal, mas ao vazio de toda perspectiva realista que confunde "minha representação" e "objetidade em si". Apenas o realismo tem interesse em provas; apenas o realismo coisifica e separa o que, em si, é indissociável. O mundo como representação não significa "as coisas não são o que parecem", mas que todo objeto é intelectual. Pelo contrário, lemos Schopenhauer dizer expressamente, antes de Nietzsche: enquanto representações, as coisas são exatamente o que parecem ser! Se algo (a)parece a um e outro diferentemente, para cada um esse algo é o que parece ser. Não há como defendermos que pode parecer bom para mim o que me parece mau, parecer alto para mim o que me parece baixo. O sujeito é o locus das significações representadas, mas não a 
última instância do sentido geral da existência, pois essa reside na vontade que nele se manifesta e segundo a qual cada experiência pode adquirir esse ou aquele significado. Se os significados podem variar conforme o contexto, a situação histórica, etc., nem por isso perdem algo de sua "realidade"; apenas se deve atentar para o fato de que nenhuma explicação psicológica, sociológica, histórica ou científica será capaz de desvincular-se das relações entre representações e, assim, chegar ao âmago das coisas. A "idealidade transcendental", pois, não é uma ponte que nos liga ao mundo como algo exterior real, mas representa, ao contrário, que, fora do âmbito das meras representações do intelecto, a ponte é impossível senão ilusoriamente. Justamente por, em si, nós e o mundo sermos o mesmo, a diferença ôntica é intransponível ${ }^{7}$, pois a natureza de sua ligação essencial, apenas simulada pela via do conhecimento, é por princípio alheia à causalidade.

[...] entre nós e o mundo, há sempre a ideia que temos dele, e esta ideia pode tornar a natureza inacessível ao homem, e o homem estranho à natureza. Somente nas crianças e nos homens muito incultos tal barreira é por vezes bastante frágil, para que um simples golpe de vista lançado sobre aquilo que os cerca baste a nos instruir sobre o que se passa neles"8.

A ilusão produzida pela experiência da causalidade consiste na convicção de que podemos tomar qualquer coisa como efeito remissível a uma causa, até que seja necessária uma causa-primeira, cuja realidade, para ser também provada, jamais deixou de gerar problemas que ameaçam a própria filosofia. Para Schopenhauer ${ }^{9}$, esse destino foi traçado desde o começo.

[...] desde Platão e Aristóteles, a filosofia em grande parte foi apenas um longo abuso dos conceitos gerais, como, por exemplo, a substância, o princípio, a causa, o bem, a perfeição, a necessidade, etc. Essa tendência

7 Se, para Schopenhauer, isso tem relação com a incognoscibilidade da coisa em si, ou seja, do que algo é essencialmente, Husserl e Heidegger irão além da tematização psicológica. O caráter instransponível consiste na transcendência, e nisto se radica a crítica de Husserl a Hume. Diz HUSSERL, E. A ideia de fenomenologia. Lisboa: Edições 70, [s. d.], p. 43: "Porventura, a psicologia de Hume não transcende, como toda a psicologia, a esfera da imanência? Não opera ela, sob as rubricas de 'hábito', 'natureza humana' [human nature], 'órgão sensorial', 'estímulo', etc., com existências transcendentes (e transcendentes, segundo a sua própria confissão), quando o seu objetivo é rebaixar ao nível da ficção todo o transcender as 'impressões' e 'ideais' atuais?". Do ponto de vista fenomenológico, a transcendência é transposta pela intencionalidade.

8 Cf. SCHOPENHAUER, A. Le monde comme volonté e comme représentation, Cap. V, p. 735.

9 Ibid., Cap. IV, p. 714/716/718. 
dos espíritos de operar com conceitos abstratos e de uma extensão desmedida se reencontra em quase todas as épocas; talvez ela provenha de uma certa preguiça da inteligência, que acha muito penoso controlar [kontrolieren] o pensamento pela intuição. Pouco a pouco esses conceitos demasiado estendidos são empregados similarmente a signos algébricos, e, como eles, introduzidos em toda parte e em todos os sentidos; daí vem que a filosofia não passa de uma arte de combinar, um modo de cálculo que, como toda operação numérica, apenas ocupa e exige faculdades inferiores. Que digo? Ela degenera em simples verborreia [...] a filosofia não é, como Kant a define, uma ciência de conceitos [aus Begriffen], mas uma ciência em conceitos [in Begriffen]. [...] Uma enorme extensão in abstracto do conceito de causalidade conduziu a estender a causa até o objeto [das Ding] tomado absolutamente, depois a sua essência [Wesen] inteira, a sua existência [Daseyn], e enfim a matéria, tanto que, no fim das contas, se encontrou autorizado a questionar uma causa do mundo; e é daí que saiu a prova cosmológica. Ela consiste em concluir, sem estar de modo algum autorizada para tanto, da existência do mundo, sua não-existência anterior; depois, enfim, com, com uma inconsequência assustadora, suprime aquela lei de causalidade, da qual tira toda sua força, detendo-se em um primeiro princípio, sem querer ir mais além; eis o que é terminar com um verdadeiro parricídio [...].

A procura por um começo do mundo leva necessariamente a aporias, a não ser que arbitrariamente se lhe atribua, não sem paradoxo ou artifícios ad hoc, uma causa-primeira que, ao mesmo tempo causa-de-simesma, não proceda nenhuma outra - eis o parricídio: para se sustentar uma lei da causalidade, necessária a toda explicação, sem se cair em um regresso ao infinito que anularia seu poder explicativo, é necessário postular uma causa-primeira não causada. Isso porque o "mundo" para o qual se busca aí um começo consiste na totalidade, o começo de tudo. Artifício ad hoc seria, portanto, imaginar algo que é além de tudo. Por sua vez, a prova cosmológica já deve pressupor, enquanto "prova", tanto a causalidade quanto a causa-primeira não causada, a fim de, partindo do suposto efeito dado, chegar a um princípio desconhecido. O pensamento teológico, e por essa expressão entendemos também o mais rudimentar dos mitos cosmológicos, sempre apaziguou a angústia do "nada antes", do "nada fora do mundo". À medida que a razão encontra problemas cada vez mais insolúveis com relação a esse tão antigo pressuposto, vendo-se obrigada a provar a realidade do mundo independentemente da existência dos deuses, mais aquele fora se converte em algo interior ao espírito humano, um simples ponto de fé, que deixa de nos aterrorizar e passa a servir de calmante para as aflições do dia-a-dia, um deus pessoal com quem se adquire intimidade. De outro lado, nada mais é fora do mundo, e o cosmos deve então ser entendido por uma física como fruto de si mesmo, o primeiro princípio é agora um primeiro elemento 
químico a que todo o resto pode ser reduzido, com o qual toda matéria mantém parentesco. Evade-se da pergunta sobre a proveniência de tal elemento, postula-se a sua eternidade e relativiza-se tempo e espaço. Nesse processo de fisicalização do mundo, perde-se de vista a própria natureza da pergunta inicial, que, no fundo, não diz respeito tanto à realidade do mundo atual, que não passa de problema de psicologia, mas à (im)possibilidade de o mundo ter tido um começo. Acontece que a resposta é impossível justamente porque o seu objeto - a causa-primeira do mundo, sem a qual, já ensinara Aristóteles, nada atual poderia ser explicado -, simplesmente não existe, senão aos olhos de um sujeito. Não suportamos, no entanto, aceitar que o mundo tenha tido início conosco, mesmo porque isso significaria que toda a história pregressa é falsa, jamais se deu, que o tempo e o espaço em que se construíram e se destruíram tantas coisas não têm nenhuma realidade independentemente de nossas representações. Justamente o que não se quer aceitar é que a tão evidente "totalidade" seja apenas representação. De que adiantaria um deus, quando perdemos a fé em nós mesmos? Na impossibilidade de garantir os nossos preconceitos, preferimos adequá-los a nossas possibilidades de conhecimento, que sempre deve partir de algo dado: um primeiro elemento.

Indo mais a fundo do que Schopenhauer ou Nietzsche, Heidegger, com a definição da essência do homem como ser-no-mundo, aprimora a tese da indissociabilidade entre eu e mundo. Tal indissociabilidade traz estranhamento por desqualificar a polarização sujeito-objeto, forma de toda possibilidade de conhecimento posta pelas formas de tempo e espaço, conforme já ensinara Schopenhauer. Para além dessa dicotomia, nada é na medida em que tudo é indeterminado - trata-se do aberto, do livre. O Dasein, já sempre sendo em um mundo, pois esse é o seu modo de ser, apenas pelo desenraizamento na fuga decadente, quando dotado de uma compreensão imprópria de si mesmo, distinguindo-se como ente simplesmente dado em meio a outros, pode perguntar-se sobre a realidade do mundo exterior. Para Heidegger ${ }^{10}$, o "escândalo da filosofia" consiste em "sempre ainda se esperar e buscar" uma prova para a realidade. Isso, segundo ele, denuncia a condição do "sujeito desmundanizado ou inseguro acerca de seu mundo que, antes de tudo, precisa assegurar-se de um mundo", como se as provas não fossem suficientes, quando, na verdade, é o Dasein a resistir a tais provas na medida em que "já sempre é, em seu ser, aquilo que as provas posteriores supõem como o que se

10 Cf. HEIDEGGER, M. Ser e tempo. Trad. e apres. Marcia Sá Cavalcante Schuback. Posfácio Emmanuel Carneiro Leão. Petrópolis-Bragança Paulista: Vozes-Edusf, 22007, § 43, p. 274-275. 
deve necessariamente demonstrar". A resistência do Dasein a provas denuncia a própria "ilegalidade" das questões, as quais, como viemos fazendo, não devem ser por isso postas à parte, mas consideradas em seu sentido, em sua dimensão existencial.

Enfim, a continuidade da fuga supõe a produção de dúvidas que, rompendo a familiaridade com o habitual, proporcionem a cada vez a reiteração da confiança na razão sempre incapaz de tudo conhecer. Tal confiança, por sua vez, é o que garante o sentimento de controle necessário à fuga da sempre iminente possibilidade do enigma. Sendo nós mesmos os produtores de enigmas, ao mesmo tempo em que reafirmamos o controle da natureza, elevamos a confiança na racionalidade que sempre haverá de nos salvar das adversidades. Assim se dá o enclausuramento da vontade, fugindo do nada, no mundo como representação. Enquanto isso, encobrimos os enigmas autênticos da existência, para os quais

[...] nenhuma ciência, no sentido exato da palavra (quero dizer um todo de conhecimentos sistematizados com a ajuda do princípio de razão), é apropriada para fornecer uma solução definitiva, nem uma explicação plena da realidade; a ciência, com efeito, jamais saberia penetrar até a essência íntima do mundo; jamais ultrapassa a simples representação, e, no fundo, somente dá a relação entre duas representações ${ }^{11}$.

Uma vez que o conteúdo das ciências está restrito à "relação de representações entre si, em conformidade ao princípio de razão e em vista do porquê, que não tem valor e sentido senão por esse princípio", o papel da ciência consiste em mostrar aquela relação, isto é, explicar, não havendo mais porquês a se perguntar para além de tais relações ${ }^{12}$. Desse modo, "a explicação pelas causas não é jamais absoluta e exaustiva, ela nos reenvia sempre a forças naturais, condição das relações de causalidade, e cuja essência é justamente a Vontade como coisa em si" ${ }^{13}$. Trata-se sempre de explicações relativas, razão pela qual "a explicação física", isto é, pelas causas, "tem necessidade de uma explicação metafísica que lhe dê a chave de todas as suas suposições", mesmo porque "o intelecto não é destinado primitivamente a nos instruir sobre a essência das coisas, mas somente a nos mostrar as relações com nossa vontade", ou seja, objetos de interesse, "somente o invólucro exterior, não o cerne das coisas" ${ }^{14}$. Essa essência permanece o enigma do mundo, cuja solução "é necessariamente qualquer coisa

11 Cf. SCHOPENHAUER, A. Le monde comme volonté e comme représentation, § 7, p. 56.

12 Ibid., § 15, p. 119.

13 Ibid., Cap. XIV, p. 823.

${ }^{14}$ Ibid., Cap. XVII, p. 867/870. 
que o intelecto humano é absolutamente impotente para captar e pensar"15. Por isso, diz Schopenhauer ${ }^{16}$, há "a necessidade de se procurar alhures, não no universo como tal, e em outra coisa que não a representação, a essência íntima do mundo". Afinal, uma vez que o princípio de razão não explica os fenômenos eles mesmos, mas apenas o seu encadeamento, essa deve ser a tarefa da filosofia, que "não pode ser a investigação de uma causa eficiente ou de uma causa final"17. A filosofia, entendida como o mesmo que metafísica por Schopenhauer, é a "teoria da consciência e de seu conteúdo ou do todo da experiência enquanto tal"18. A filosofia, portanto, consiste na "inteligência exata e universal da experiência mesma, a explicação verdadeira de seu sentido e de seu conteúdo", a saber, "a coisa metafísica, cujo fenômeno é apenas a vestimenta e o invólucro", estando "para o fenômeno como o pensamento para as palavras"19. Tal metafísica deverá ser, segundo as próprias palavras de Schopenhauer ${ }^{20}$, retomadas por Safranski (1991), uma metafísica imanente. Significa dizer que a essência, a "coisa metafísica", "jamais pode ser completamente destacada do fenômeno e ser considerada como um ens extramundanum", mas como "aparecendo na natureza", "jamais inteiramente destacada da experiência", uma vez que só se pode tratar da coisa em si mediante as suas relações com o fenômeno, o que não nos autoriza, por sua vez, a tratá-la como fenômeno e, portanto, sob o princípio de razão.

Tanto quanto permaneçamos no conhecimento intuitivo, tudo é para nós lúcido, assegurado, certo. Aqui, nem problemas, nem dúvidas, nem erros, nenhum desejo, nenhum sentimento do além; repousa-se na intuição, plenamente satisfeito com o presente. Tal conhecimento se basta a si mesmo; também, tudo o que procede simples e fielmente dele, como a verdadeira obra de arte, jamais corre o risco de ser falseado ou desmentido; pois ele não consiste em uma interpretação qualquer, é a própria coisa. Mas com o pensamento abstrato, com a razão, se introduzem na especulação a dúvida e o erro, na prática, a ansiedade e o ressentimento" 21 .

Desconsiderando-se o fato de Schopenhauer ainda se encontrar muito preso à psicologia moderna, a esta altura se faz bastante mais claro o

15 Ibid., Cap. XVII, p. 881.

16 Ibid., § 7, p. 64.

17 Ibid., § 15, p. 121.

18 Ibid., Cap. XII, p. 813.

19 Ibid., Cap. XVII, p. 880.

20 Ibid., Cap. XVII, p. 879.

${ }^{21}$ Ibid., § 8, p. 64. 
sentido de seu esforço filosófico. Assim como permitia laconicamente a qualificação "pessimista" por se opor ao otimismo, defendia ardorosamente a intuição contra a abstração. Essa defesa é, no entanto, bastante escusável se damos primazia ao que o filósofo pretende dizer com "intuição" e levamos em conta que, neste trecho, "a própria coisa" significa não uma essência, mas a representação como representação imediata, âmbito no qual exclusivamente as relações causais são legítimas e reais. Que o termo "intuição" significa "conhecimento imediato", disso não há dúvidas, mas deve ficar claro que isso não deve ser entendido sob qualquer ponto de vista do realismo que tanto combateu Schopenhauer e de que acusou todos os seus predecessores - nisso mesmo Schopenhauer via a si próprio como um inovador, sem qualquer modéstia. A segurança, certeza e correção do conhecimento intuitivo, em Schopenhauer, nada têm a ver com aquilo que é buscado pelo conhecimento abstrato, como, por exemplo, provas para a existência real de Deus ou do mundo. Recordando uma citação feita mais acima, o que a intuição nos dá é o conhecimento do fenômeno pelo que ele é: a minha representação. Uma vida meramente intuitiva seria marcada pela paz do animal, por sua resistência à dor, pela legitimidade de sua luta constante pela sobrevivência, enfim, pelas qualidades em que Nietzsche enxergaria a força. A relação do homem com o mundo, mediada pela razão, se converte em sofrimento graças àquilo que fantasia acerca de si mesmo e do que o cerca, para o que comumente se empenha em encontrar alguma cura, alguma salvação. $\mathrm{Na}$ verdade, todo esse sofrimento, as dores do mundo, não provém do mundo, mas do próprio homem enredado em abstrações. A fuga da dor é que produz a necessidade de remédios quaisquer, não apenas para o corpo, mas especialmente para a alma. Como é sabido, sobretudo pela crítica nietzscheana, o problema de Schopenhauer é lamentar essa fatalidade. Lamentando-a, ainda apresenta traços da referida vontade de verdade cujo desmascaramento ainda estava por vir.

No tempo de Schopenhauer, o mundo já se encontrava suficientemente des-sacralizado. Após Reforma e Contra-Reforma, revoluções burguesas e a decorrente laicização generalizada, os sistemas alemães sobre o Absoluto, a que se seguiria o positivismo, marcam a trajetória que culmina na "morte de Deus" segundo as razões iluministas. O último estágio do niilismo, após a vontade de dúvida e como sua consequência, é a inversão dos valores. Se o entendimento do mundo pelas ciências não comporta uma causa transcendente, e Deus se torna um mero consolador de consciências privadas, declara-se como verdade a não-existência de Deus ou qualquer outra coisa de imponderável, incalculável, inexperimentável. Paradoxalmente, é o supersticioso realismo positivista que consolida o mito da racionalidade causal. $O$ ateísmo se torna verdade porque a 
verdade não admite os enigmas da própria racionalidade causal. Como observa Machado22, em sua base "o que se encontra é a vontade de verdade que acaba se proibindo a mentira da fé em Deus. [...] A posição de Nietzsche é clara: o ateísmo é o aperfeiçoamento, o refinamento da vontade de verdade criada pelo platonismo e pelo cristianismo". Com isso, é claro, não se supera o niilismo e a sua vontade de verdade; antes se os aprofunda, quando até mesmo Deus é destituído de valor. No entanto, como o niilismo é ambíguo, Nietzsche ainda reconhece aí, com aguda perspicácia, uma via de escape e liberação que passa necessariamente por essa inversão rumo à transvaloração.

O ateísmo incondicional e reto (e somente seu ar é o que respiramos, nós, os homens mais espirituais dessa época!) não está, portanto, em oposição a esse ideal [ascético], como parece à primeira vista; é, isto sim, uma das últimas fases do seu desenvolvimento, uma de suas formas finais e consequências internas - é a apavorante catástrofe [reviravolta] de uma educação para a verdade que dura dois milênios, que por fim se proíbe a mentira de crer em Deus" 23 .

A "educação para a verdade que dura dois milênios" é, sem dúvida, a evangélica, que nos últimos tempos busca se salvaguardar da destruição, apoiando-se até no que a contraria por princípio - a fenomenologia, o existencialismo, a própria filosofia nietzscheana. Contudo, porque Nietzsche insiste em vincular tal educação a Platão? Não apenas por afinidades produzidas no próprio seio da teologia moral do Cristianismo. Como fazer remeter ao próprio Platão, à sua própria responsabilidade, toda a tradição metafísica - leia-se filosófico-científica - que determinou os caminhos do Ocidente desde então? Não seria o seu moralismo, senão mediatamente, mas o seu fundamento, nutriz de toda possibilidade futura de fundamentação. O que pretendemos dizer? Seria fazer injustiça a Aristóteles responsabilizá-lo por sistematizar as condições do conhecimento científico. O seu mestre Platão, mais precisamente no diálogo Mênon, dera o passo inicial, o passo que o próprio Aristóteles não se atrevera a dar - mais que isso, poderíamos supor que as suas "condições", o seu Organon, se destinavam antes a contornar o problema da fundamentação dos saberes. Platão exigia algo de muito mais radical. O fundamento último de todo saber deveria extrapolar as condições da ciência - mas, ainda assim, uma causa -, e para tanto a causa última de todo conhecimento deveria provir da pura "contemplação" (theoria), prescindindo de toda mediação. Eis a raiz da doutrina das ideias.

${ }^{22}$ Cf. MACHADO, R. Zaratustra: tragédia nietzschiana, p. 64.

23 Cf. GM, III, § 27. 
O problema a ser resolvido era, nas palavras do jovem Mênon: "E de que modo procurarás, Sócrates, aquilo que não sabes absolutamente o que é?" 24 . Ou seja, seria sempre necessário remeter o desconhecido a algo conhecido de modo ainda obscuro. Por exemplo: o que conhecemos da espécie "homem" é o que se reduz a algum gênero, algum conceito, "mamífero", "bípede", "ser animado", "ser vivo", "ser racional", etc. No entanto, ascendendo na ordem das classes, chega-se a um ponto do qual é impossível ir além, e era isso cujo ser Platão desejava conhecer: a coisa ela-mesma, não remetida a uma multiplicidade de casos. Por isso Sócrates não aceita exemplos; ele busca o modelo, a forma ou ideia. A compreensão de qualquer conceito sem remissão a qualquer outro é algo além de qualquer possibilidade de representação discursiva; trata-se de algo que pode apenas ser intuído e cuja verdade é uma certeza da alma, uma "opinião correta" (orthodoxia). A solução platônica não foi, como se deveria esperar, que de fato podemos procurar o que não conhecemos, mas sim que podemos re-conhecer o que sabemos desde a eternidade, que podemos trazer à luz da consciência o que a alma sabe e se encontra oculto para nós, que o conhecimento das ideias é o "des-ocultamento" (aletheia) do já sabido. Eis a possibilidade última de sentido para Platão.

A inversão do platonismo, pois, representa a inversão da metafísica, de que o cristianismo é parte integrante, assim como as oposições entre otimismo e pessimismo, racionalismo e ceticismo, bem e mal, teísmo e ateísmo. Nietzsche apenas indicou a sua superação, e podemos dizer que Heidegger assumiu o seu projeto, ou pelo menos fez dele, como ninguém, uma questão digna de ser pensada. A questão do homem é a questão da existência, da liberdade, da ciência, do cuidado. O empenho na produção de saberes será um dos temas mais privilegiados no pensamento heideggeriano, que o trata orientando-se pela questão sobre a essência da técnica. Enquanto continuador de Nietzsche, Heidegger assume para si a tarefa de colocar o problema da metafísica e prosseguir no acabamento do niilismo, ou seja, a conversão do niilismo passivo (negador, inversor) em niilismo ativo (afirmador, superador), já preconizado por Nietzsche. Segundo nos diz Nietzsche (CI) nas "Incursões de um extemporâneo", $\S 43$ ("Dito ao pé do ouvido para os conservadores"): "Não adianta nada: é preciso seguir em frente, quer dizer, passo a passo cada vez mais profundamente na décadence (esta é a minha definição do 'progresso' moderno...). Pode-se obstaculizar este desenvolvimento, e, através desta obstaculização, represar, recolher, tornar mais veemente e mais

${ }^{24}$ Cf. PLATÃO. Mênon. Edição bilíngue grego-português. Trad. Maura Iglésias. São Paulo - Rio de Janeiro: Loyola - PUC-Rio, 2005, 80d, p. 49. 
súbita a degeneração mesma: mais não se pode fazer" ${ }^{25}$. Trata-se da necessidade de acabamento do niilismo. Encerramos então o presente ensaio com as palavras de Schopenhauer, que, diagnósticas, repercutiram decisivamente no projeto nietzscheano. Logo a seguir, mencionamos o diagnóstico do próprio Nietzsche:

Mais nosso conhecimento da essência dos objetos particulares seja completo e exato, mais imperiosamente se nos imporá a necessidade de explicar o todo e o geral, e mais o conhecimento empírico desse elemento geral terá sido justo, preciso e completo, mais misterioso e mais enigmático nos parecerá. [...] Ressaltemos, portanto, por outro lado, que um conhecimento tão completo quanto possível da natureza é necessário para se colocar com precisão o problema da metafísica ${ }^{26}$.

[...] a ciência é hoje um esconderijo para toda espécie de desânimo, descrença, remorso, despectio sui [desprezo de si], má consciência - ela é a inquietude da ausência de ideal, o sofrimento pela falta do grande amor, a insatisfação por uma frugalidade involuntária. [...] A competência dos nossos melhores doutores, sua impensada diligência, sua cabeça a fervilhar dia e noite, mesmo sua mestria no ofício - com que frequência o sentido de tudo isso esteve em não deixar que uma coisa se tornasse clara para si próprio! A ciência como meio de autoanestesia: vocês conhecem isto?... [...] sofredores que não querem confessar a si mesmos o que são, $[\ldots]$ gente entorpecida e insensata que teme uma só coisa: ganhar consciência..."27.

\section{Referências}

HEIDEGGER, M. Ser e tempo. Trad. e apres. Marcia Sá Cavalcante Schuback. Posfácio Emmanuel Carneiro Leão. Petrópolis-Bragança Paulista: Vozes-Edusf, ${ }^{2} 2007$.

HUME, D. Investigação acerca do entendimento humano. Trad. Anoar Félix. São Paulo: Nova Cultural, 1996 (Coleção Os Pensadores), p. 17-154.

HUSSERL, E. A ideia de fenomenologia. Lisboa: Edições 70, [s. d.].

MACHADO, R. Zaratustra: tragédia nietzschiana. Rio de Janeiro: J. Zahar, 1997.

NIETZSCHE, F. W. Além do bem e do mal: prelúdio a uma filosofia do futuro. Trad. Paulo César de Souza. São Paulo: Companhia das Letras, 1996.

. Genealogia da moral: uma polêmica. Trad. Paulo César de Souza. São Paulo: Companhia das Letras, 1999.

${ }^{25}$ NIETZSCHE, F. W. Crepúsculo dos ídolos: ou como filosofar com o martelo. Trad. Marco Antonio Casa Nova. Rio de Janeiro: Relume Dumará, 2000, p. 100.

${ }^{26}$ Cf. SCHOPENHAUER, A. Le monde comme volonté e comme représentation, Cap. XVII, p. 872-873.

27 Cf. GM, III, § 23. 
NIETZSCHE, F. W. Crepúsculo dos ídolos: ou como filosofar com o martelo. Trad. Marco Antonio Casa Nova. Rio de Janeiro: Relume Dumará, 2000. (Coleção Conexões). 2004. . A gaia ciência. Trad. Paulo César de Souza. São Paulo: Companhia das Letras,

PLATÃO. Mênon. Edição bilíngue grego-português. Trad. Maura Iglésias. São Paulo; Rio de Janeiro: Loyola; PUC-Rio, 2005.

SAFRANSKI, R. Schopenhauer y los años salvajes de la filosofia. Madri: Allianza, 1991.

SCHOPENHAUER, A. Le monde comme volonté e comme représentation. Trad. A. Burdeau. 2. ed. rev. e corr. por Richard Ross. Pref. Clément Rosset. Paris: Presses Universitaires de France, 2004. (Collection Quadrige).

\section{Endereço postal:}

Rua São Cristóvão, 95, ap. 302 - Lagoa Nova

59056-290 Natal, RN, Brasil

E-mail: oejeblik@yahoo.com.br.

Data de recebimento: 10/06/2013

Data de aceite: 15/08/2013 